УДК 532.785:538.91

DOI: $10.17308 / \mathrm{kcmf} .2019 .21 / 1150$

Поступила в редакцию 30.08.2019

Подписана в печать 15.09.2019

\title{
КОЛЛЕКТИВНАЯ ДИНАМИКА И РАЗМЕРНЫЕ ЭФФЕКТЫ ФАЗООБРАЗОВАНИЯ В СИСТЕМЕ АЭРОСИЛ - ПОЛИСТИРОЛЬНЫЙ ЛАТЕКС
}

\author{
@2019 И. И. Долгих, Д. А. Жукалин ${ }^{\bowtie}$, Л. А. Битюцкая \\ Воронежский государственный университет \\ Университетская пл., 1, 394018 Воронеж, Российская Федерация
}

\begin{abstract}
Аннотация. В стандартных условиях проведен эксперимент по влиянию сил обеднения на процесс высыхания капли взвесей невзаимодействующих частиц аэросила и полистирольного латекса. Впервые обнаружен быстропротекающий процесс фазового превращения кристаллического аэросила в кристаллический $\mathrm{SiO}_{2}$ в течение десятков секунд, сопровождающийся резким изменением цвета раствора капли от светло-голубого до синего. Зарегистрирована микродифракция, свидетельствующая о нанокристаллической природе зародышеобразования новой фазы. Образование нанокристаллической фазы интерпретировано как результат действия неравновесной силы обеднения в условиях гидродинамической неустойчивости высыхающей капли. Вычислительный эксперимент в статистической модельной системе жестких невзаимодействующих сфер подтвердил предлагаемый механизм фазообразования в условиях стеснения.
\end{abstract}

Ключевые слова: капля, нанореактор, самоорганизация, наносистема, силы обеднения, фазообразование, коллективная динамика.

\section{ВВЕДЕНИЕ}

Структурная эволюция высыхающих капель коллоидных растворов на гидрофильной подложке представляет собой комплекс сложных физико-химических и механических процессов, объединяемых понятием дегидратационная самоорганизация [1-3]. Высыхающая капля рассматривается как нанореактор с постоянно меняющимися параметрами: концентрация, радиус кривизны, поверхностное натяжение, температура. Наряду с биологической и медицинской диагностикой, самосборкой наночастиц и другими применениями «капельный нанореактор» представляет большой интерес при синтезе наноструктурированных материалов."

За последние несколько десятилетий разработано множество методов синтеза наночастиц контролируемой формы, размера и дисперсности для большого числа материалов. Кроме характеризации оптических, электронных, механических и каталитических свойств отдельных наночастиц, большое внимание уделяется разработке методов сборки наночастиц в большие упорядоченные или разупорядоченные сверхструктуры.

\footnotetext{
$\triangle$ Жукалин Дмитрий Алексеевич,
} e-mail:d.zhukalin@mail.ru
Эти методы сборки базируются на существовании множества различных типов межчастичных взаимодействий (Ван-дер-ваальсовые, магнитные, электростатические, молекулярные дипольные, ковалентные и водородные связи). Большая часть этих взаимодействий имеют заданное направление либо действуют лишь на определенных расстояниях, и только электростатические взаимодействия [4] могут быть как притягательными, так и отталкивающими, а их сила и дальность действия определяется зарядом на поверхности наночастиц, диэлектрической проницаемостью среды и концентрацией ионов, присутствующих в растворе.

В последнее время для изучения раннего структурообразования (коагуляции) в коллоидных системах используют капельный метод [5, 6]. Капельный метод широко применяется на практике, например, он лежит в основе аналитических методов идентификации неорганических [7] и органических (биологических) веществ [8]. Явление дегидратационной самоорганизации жидкости запатентовано. При кажущейся простоте метод оказался чрезвычайно сложным физико-химическим процессом [9-11]. За годы исследований направление изучения процессов

Контент доступен под лицензией Creative Commons Attribution 4.0 License.

The content is available under Creative Commons Attribution 4.0 License. 
испарения стало междисциплинарным, привлекая внимание физиков, химиков, биологов и математиков. Интерес к физике процесса испарения капли растет с каждым годом как со стороны теоретиков [12], так и практиков [13].

При взаимодействии частиц в высыхающей капле необходимо учитывать силы обеднения. Одним из первых эффект был описан профессором Асакурой в работе, посвящённой исследованию взаимодействия между частицами, суспендированными в растворах макромолекул [14].

Традиционно силы обеднения рассматриваются в контексте взаимодействия двух частиц раствора для определения их взаимодействия. Важно, что эффект Асакуры наблюдается для частиц компонентов, отличающихся по размеру в 4 и более раз. Целью данной работы является изучение фазового поведения двухкомпонентной коллоидной взвеси аэросил - латекс в условиях краудинга.

\section{ЭКСПЕРИМЕНТАЛЬНАЯ ЧАСТЬ}

В качестве исходных материалов использовались коллоидные взвеси аэросила в концентрации $0.1 \mathrm{mg} / \mathrm{ml}$ с размером частиц $100 \mathrm{~nm}$ и полистирольный латекс с размером частиц $20 \mathrm{~nm}$ в концентрации $10 \mathrm{mg} / \mathrm{ml}$. Для приготовления однородных коллоидных взвесей заданной концентрации использовали ультразвуковой диспергатор УЗГ-13. Размеры частиц получившихся взвесей контролировали методом светорассеяния на измерителе размеров частиц Photocor mini. Проводился сравнительный анализ процессов высыхания капли исходных компонентов и смеси в динамическом режиме in situ. Опыты проводились в стандартных условиях. Использовался оптический микроскоп Bresser Advance ID с цифровой регистрацией.

Морфология и идентификация продуктов высыхающей капли производилась комплексом методов, включающих ИК спектроскопию Bruker VERTEX 70, растровая микроскопия - Jeol JSM-6380LV и просвечивающая микроскопия LIBRA 120 PLUS.

\section{РЕЗУЛЬТАТЫ И ИХ ОБСУЖДЕНИЕ}

При регистрации процесса высыхания капли исходных компонентов - аэросила и полистирольного латекса наблюдается типичная картина для однокомпонентной системы, включающая кофейное кольцо. При высыхании капли смеси аэросила и ПЛ происходит осаждение конденсированного осадка с несколькими поблескивающими микрочастицами в результате образования и быстрого роста новой фазы микроскопических размеров до десяток микрон в течение десятков секунд (рис. $1 a, b)$. Цвет раствора меняется от прозрачного до синего. При этом происходит образование новой фазы локализуется в центральной области капли.

Идентификация методом ИК-спектроскопии продуктов высыхания проводилась в сравнении с исходными компонентами. Сравнительный анализ показывает характеристические спектры исходных чистых компонентов аэросила и полистирольного латекса (рис. 1c). Образование новой фазы не привело к заметному изменению спектров исходных компонентов. Небольшое искривление пика, отвечающего за связь $\mathrm{Si}-\mathrm{O}$, вызванное изменением соотношения продольной и поперечной компоненты колебаний, может быть вызвано механической деформацией. Таким образом, можно считать, что новая фаза является оксидом кремния.

Отметим, что данный эффект характерен для динамической системы ограниченного объема, каковой является капля. В макроскопических объемах эффект не наблюдается.

При исследовании на растровом микроскопе продуктов высыхания капли наблюдается конгломерат новой фазы и латекса в исходном состоянии. Это подтверждает химическую инертность компонентов и механическую природу их взаимодействия.

Для определения кристаллической структуры фазы нанокристаллы из осадка высохшей капли исследовались на просвечивающем электронном микроскопе. Дифракционная картина, свидетельствующая о нанокристаллической природе зародышеобразования новой фазы (рис. 2c). Симметрия расположения отражений на микродифракционной картине (рис. 2c) предполагает одновременное попадание под электронный пучок двух сросшихся нанокристаллов,один из которых развернут к пучку плоскостью базиса гексагональной/тригоналтной элементарной ячейки , а второй плоскостью, перпендикулярной к этой плоскости.

Для Для понимания механизма фазообразования нами проводился вычислительный эксперимент в статистической модельной системе жестких невзаимодействующих сфер в приближении броуновского движения. Отношение радиусов взято равным 4 соответственно условиям модельного эксперимента. Наблюдается пространственное перераспределение больших частиц в присутствии маленьких, приводящее к возникновению сгущений (рис. 3). Эти сгущения могут быть ответственны за непрозрачность смеси аэросила и латекса, несмотря на прозрачность обоих компо- 


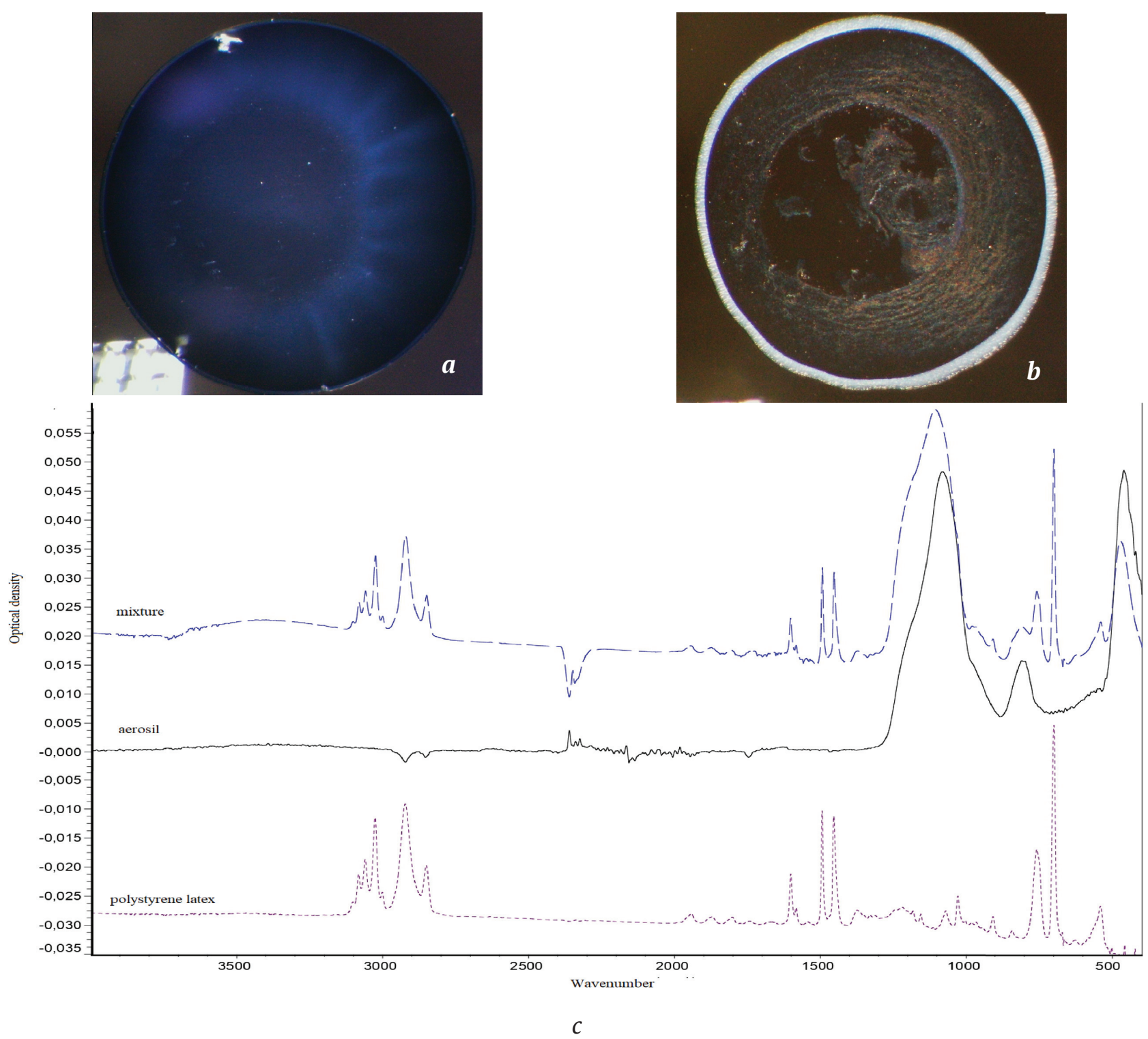

Рис. 1. Фазообразование кристаллита при высыхании капли коллоидного раствора в системе аэросил - полистирольный латекс: $a, b$ - под оптическим микроскопом; $a$ - в процессе высыхания; $b$ - после высыхания; $c$ - ИК спектры продуктов высыхания

[Fig. 1. Phase formation of crystallite upon drying of a drop of colloidal solution in the aerosil -polystyrene latex system: $a, b$ - under an optical microscope; $a$-in the drying process; $b$ - after drying; $c$ - IR spectra of the drying products]

нентов, и за образование новой фазы. Эти сгущения возникают под действием силы обеднения.

Обычно при рассмотрении взаимодействия частиц в растворе их можно считать идеальным газом. Учет размера и формы частиц приводит к поправкам на силу обеднения [14], которые управляют высотой порога активации, скоростью и направлением реакции [15]. В ряде случаев сила обеднения является уже не поправкой, а основной движущей силой процессов в растворе, превосходя другие силы [16], и может даже собирать вместе отталкивающиеся частицы [17]. Сила обеднения становится велика, когда частицы занимают большую часть предоставленного им объема, а пространство для их движения мало. Этим условиям отвечает модельный опыт. Такое стесненное состояние называется краудингом [18]. Проведение реакции в высыхающей капле является типовым способом получения краудинга. В этом случае объемом раствора управляют, контролируя процесс высыхания [19]. Краудинг можно получить не только за счет высокой концентрации компонентов и малого объема, но и локально на неоднородностях раствора. Для этого используются различные методы локального воздействия. Например, нагрев точки, приводящий к большим 


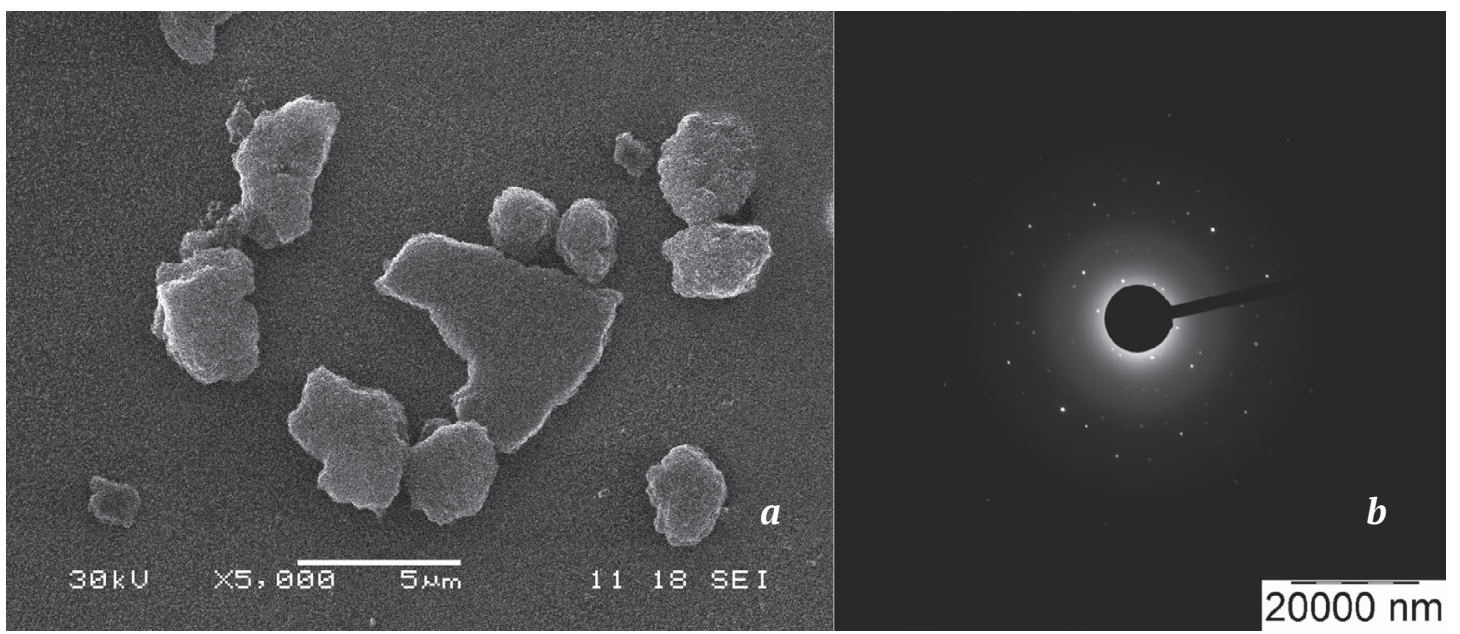

Рис. 2. Фазообразование кристаллита $\mathrm{SiO}_{2}$ в капельном нанореакторе: $a$ - растровая электронная микроскопия; $b$ - дифракционная картина просвечивающей электронной микроскопии

[Fig. 2. Phase formation of crystallite $\mathrm{SiO}_{2}$ at droplet nanoreactor: $a$ - scanning electron microscopy; $b$ - diffraction pattern of transmission electron microscopy]

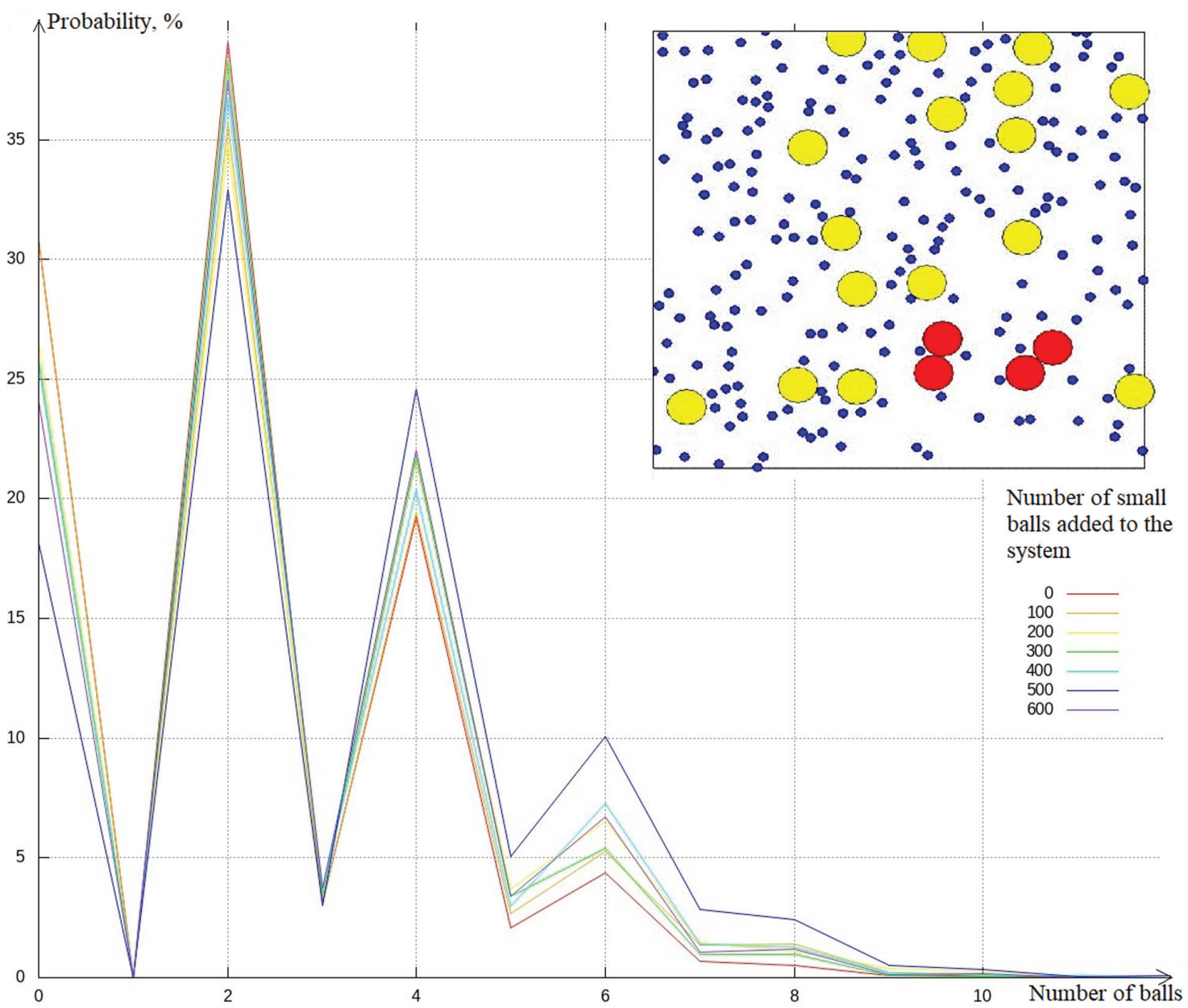

Рис. 3. Вычислительный эксперимент. Произвольный момент динамики сфер - цветом выделены сблизившиеся сферы. На графике показана вероятность обнаружить такое количество больших сфер, сблизившихся в зависимости от концентрации маленьких

[Fig. 3. Computational experiment. Arbitrary moment of the dynamics of the spheres - the clustered spheres are pointed out with color. The graph shows the probability of detecting such a number of large spheres clustered, depending on the concentration of small ones] 
градиентам температур в её окрестности [20], импульс лазера, управляющий локальной концентрацией магнитных частиц, приводя к возникновению коллоидного кристалла [21], и т. п. В этом случае имеется еще и дополнительный эффект сила обеднения заметно возрастает для движущихся частиц, что было изучено в вычислительных экспериментах [22]. Для получения самоорганизованных структур, как правило, используют именно неравновесную силу обеднения.

Ранее нами было показано [23], что при высыхании на хорошо смачиваемой поверхности коллоидная взвесь углеродных нанотрубок образует крупные жгуты, хорошо наблюдаемые в оптический микроскоп. Смачиваемая поверхность требуется для возникновения сильных капиллярных течений при высыхании. На гидрофобной поверхности жгуты не возникают, поскольку равновесных сил обеднения в отсутствии течений оказывается недостаточно.

\section{Выводы}

Впервые экспериментально показано, что при высыхании капли коллоидного раствора невзаимодействующих частиц в системе аэросил - полистирольный латекс происходит образование и быстрый рост новой фазы кристаллического $\mathrm{SiO}_{2}$. предположительно гексагональной/тригональной симметрии, зарегистрированной на дифракционной картине микродифракции. Процесс фазообразования сопровождается резким изменением цвета раствора со светло- голубого до синего. Размер кристаллитов варьируется в интервале от десяти нанометров до десяти микрон. Вычислительный эксперимент в статистической модельной системе жестких невзаимодействующих сфер подтвердил предлагаемый механизм фазообразования в условиях стеснения.

\section{БЛАГОДАРНОСТИ}

Авторы выражают искреннюю благодарность всему коллективу Центра коллективного пользования научным оборудованием Воронежского государственного университета. URL: http:// ckp.vsu.ru

\section{КОНФЛИКТ ИНТЕРЕСОВ}

Авторы декларируют отсутствие явных и потенциальных конфликтов интересов, связанных с публикацией настоящей статьи.

\section{СПИСОК ЛИТЕРАТУРЫ}

1. Третьяков Ю. Д. Процессы самоорганизации в химии материалов // Успехи химии, 2003, т. 72(8), с. 731-763. DOI: 10.1070/RC2003v072n08ABEH000836
2. Кушнир С. Е., Казин П.Е., Трусов Л. А., Третьяков Ю. Д. Процессы самоорганизации микро- и наночастиц в феррожидкостях // Успехи химии, 2012, т. 81(6), c. 739-760.DOI: https://doi.org/10.1070/ RC2012v081n06ABEH004250

3. Лебедев-Степанов П. В., Кадушников Р. М., Молчанов С. П., Иванов А. А., Митрохин В. П., Власов К. О., Рубин Н. И., Юрасик Г. А., Назаров В. Г., Алфимов М.В. Самосборка наночастиц в микрообъеме коллоидного раствора: физика, моделирование, эксперимент // Российские нанотехнологии, 2013, т. 8(3-4), c. 5-23. DOI: 10.1134/S1995078013020110

4. Walker D. A., Kowalczyk B., Cruz M. O., Grzybowski B. A. Electrostatics at the nanoscale // $\mathrm{Na}$ noscale, 2011, v. 3(4), pp. 1316-1344. DOI: 10.1039/ CONR00698J

5. Ouyang Q., Castets V., Boissonade J., et al. Sustained patterns in chlorite-iodide reactions in a onedimensional reactor // J. Chem. Phys., 1991, v. 95(1), pp. 351-360. DOI: 10.1063/1.461490

6. Тарасевич Ю. Ю., Православнова Д. М. Качественный анализ закономерностей высыхания капли многокомпонентного раствора на твердой подложке // ЖТФ, 2007, т. 77(2), c. 17-21.URL: https:// journals.ioffe.ru/articles/viewPDF/9047

7. Файгль Ф., Ангер В. Капельный анализ неорганических веществ. М.: Мир, 1976, т. 1, 390 с., т. 2., 320 c.

8. Яхно Т. А., Казаков В. В., Санина О. А., Санин А. Г., Яхно В. Г. Капли биологических жидкостей, высыхающие на твердой подложке: динамика морфологии, массы, температуры и механических свойств // ЖТФ, 2010, т. 80(7), с. 17-23. URL: http:// journals.ioffe.ru/articles/viewPDF/10043

9. Алфимов М. В., Кадушников Р. М., Штуркин Н. А., Алиевский В. М., Лебедев-Степанов П. В. Иммитационное моделирование процессов самоорганизации наночастиц // Российские нанотехнологии, 2006, т. 1(1-2), с. 127-133.

10. Лебедев-Степанов П. В., Громов С. П., Молчанов С. П., Чернышов Н. А., Баталов И. С., Сазонов С. К., Лобова Н. А., Шевченко Н. Н., Меньшикова А. Ю., Алфимов М. В. Управление самосборкой ансамблей модифицированных коллоидных частиц в микрокаплях раствора // Российские нанотехнологии, 2011, т. 6(9-10), с. 72-78. DOI: 10.1134/ S1995078011050119

11. Андреева Л. В., Новоселова А. С., ЛебедевСтепанов П. В., Иванов Д. А., Кошкин А. В., Петров А. Н., Алфимов М. В. Закономерности кристаллизации растворенных веществ из микрокапли // ЖТФ, 2007, т. 77(2), с. 22-30. URL: https://journals. ioffe.ru/articles/viewPDF/9048

12. Barash L. Yu. Marangoni convection in an evaporating droplet: Analytical and numerical descriptions // International Journal of Heat and Mass Transfer, 2016, v. 102, pp. 445-454. DOI: 10.1016/j.ijheatmasstransfer.2016.06.042 
13. Битюцкая Л. А., Жукалин Д. А., Тучин А. В., Фролов А. А., Буслов В.А. Тепловые диссипативные структуры при агрегации углеродных нанотрубок в высыхающей // Конденсированные среды и межфазные границы, 2014, т. 16(4), с. 425-430. URL: https://journals.vsu.ru/kcmf/article/view/856/937

14. Asakura S., Oosawa F. Interaction between particles suspended in solutions of macromolecules // Polymer Science Part A: General Papers, 1958, v. 33(126), pp. 183-192. DOI: 10.1002/pol.1958.1203312618

15. Minton A. P. How can biochemical reactions within cells differ from those in test tubes? // Journal of Cell Science, 2015, v. 119(14), pp. 2863-2869. DOI: $10.1242 /$ jcs.03063

16. Чеботарева Н. А., Курганов Б. И., Ливанова Н. Б. Биохимические эффекты молекулярного краудинга. Обзор. // Биохимия, 2004, т. 69(11), c. $1522-1536$.

17. Bishop K. J., Wilmer C. E., Soh S., Grzybowski B. A. Nanoscale forces and their uses in self-assembly // Small, 2009, v. 5(14), p. 1600-1630. DOI: 10.1002/smll.200900358

18. Minton A. P. The influence of macromolecular crowding and macromolecular confinement on biochemical reactions in physiological media // Journal of Biological Chemistry, v. 276(14), pp. 10577-10580. DOI: $10.1074 /$ jbc.r100005200

19. Huber F., Strehle D., Schnauss J., Kas J. Formation of regularly spaced networks as a general feature of actin bundle condensation by entropic forces // New J. Physics, 2015, v. 17(4), p. 043029. DOI: 10.1088/13672630/17/4/043029

20. Jiang H., Wada H., Yoshinaga N., Sano M. Manipulation of colloids by a nonequilibrium depletion force in a temperature gradient // Physical Review Letters, 2009, v. 102(20), p. 208301. DOI: 10.1103/ physrevlett.102.208301

21. Deng H., Li G., Liu H. Assembling of three-dimensional crystals by optical depletion force induced by a single focused laser beam // Optics Express, 2012, v. 20(9), p. 9616. DOI: 10.1364/oe.20.009616

22. Wulfert R., Seiferta U., Speck T. Nonequilibrium depletion interactions in active microrheology // Soft Matter, 2017, v. 13(48), p. 9093-9102. DOI: 10.1039/ c7sm01737e

23. Долгих И. И., Битюцкая Л. А. Энтропийная агрегация УНТ в высыхающей капле на гидрофильной и гидрофобной подложках // Конденсированные среды и межфазные границы, 2018, т. 20(4), с. 664668. DOI: 10.17308/kcmf.2018.20/635

UDC 532.785:538.91

DOI: $10.17308 / \mathrm{kcmf} .2019 .21 / 1150$

Received 30.08.2019

Accepted 15.09.2019

\title{
COLLECTIVE DYNAMICS AND DIMENSIONAL EFFECTS OF PHASE FORMATION IN THE "AEROSIL - POLYSTYRENE LATEX» SYSTEM
}

\author{
(c) 2019 I. I. Dolgih, D. A. Zhukalin ${ }^{\bowtie}$, L. A. Bityutskaya \\ Voronezh State University, \\ 1, Universitetskaya pl., 394018 Voronezh, Russian Federation
}

\section{Abstract}

Purpose. In addition to characterizing the optical, electronic, mechanical, and catalytic properties of individual nanoparticles, much attention is paid to the development of methods for assembling nanoparticles into large ordered or disordered superstructures. These assembly methods are based on many different types of interparticle interactions (Van der Waals, magnetic, electrostatic, molecular dipole, covalent and hydrogen bonds). Recently, the drip method has been used to study early structural formation in colloidal systems. When particles interact in a drying drop, depletion forces must be taken into account. In this paper a model experiment has been carried out to study the effect of depletion forces on phase formation during the drying process of a drop.

Methods and methodology. Colloidal suspensions of Aerosil at a concentration of $0.1 \mathrm{mg} / \mathrm{ml}$ with a particle size of $100 \mathrm{~nm}$ and polystyrene latex with a particle size of $20 \mathrm{~nm}$ at a concentration of $10 \mathrm{mg} / \mathrm{ml}$ were used as starting materials. Homogeneous colloidal suspensions of a given concentration were prepared using an ultrasonic disperser UZG-13. The particle sizes of the resulting suspensions were controlled by light scattering on a Photocor mini particle size meter. A comparative analysis of the drying process of a droplet with the initial components and with their mixture has been conducted in dynamic mode. The experiments were carried out in standard conditions. A digital optical microscope Bresser Advance ID was used to control the drying

$\checkmark$ Zhukalin Dmitry Alekseevich, e-mail: d.zhukalin@mail.ru 
dynamics. The morphology and identification of the drying products have been carried out by a set of methods, including IR spectroscopy - Bruker VERTEX 70, scanning microscopy - Jeol JSM6380LV and transmission microscopy - LIBRA 120 PLUS.

Results. When a droplet of a mixture of aerosil and latex was dried, there was observed the formation and rapid growth of a new phase of microscopic sizes up to ten microns in a matter of tens of seconds. The color of the solution changes sharply from transparent light blue to bright blue. The formation of a new phase is localized in the central region of the drop. According to the data of IR spectroscopy and of electron and transmission microscopy, the resulting phase is crystalline $\mathrm{SiO}_{2}$.

To interpret the obtained results, a computational experiment was carried out in a statistical model system of rigid non-interacting spheres in the Broun motion approximation. In the simulation the spatial redistribution of large particles in the presence of small particles is observed, leading to the occurrence of the thickenings. Phase formation is interpreted as the result of the action of the nonequilibrium depletion force under the conditions of the hydrodynamic instability of a drying drop.

Conclusions. In the conditions of a model experiment on phase formation during drying of a drop of a non-interacting particles colloidal solution in the aerosil-polystyrene latex system, the formation and rapid growth of a new phase of crystalline $\mathrm{SiO}_{2}$ has been detected. The phase formation process is accompanied by a sharp change in the color of the solution from light blue to blue. The crystallite size varies from ten nanometers to ten microns. A diffraction pattern of the new phase has been found indicating its crystalline nature.

Keywords: drop, nanoreactor, self-organization, nanosystem, depletion forces, phase formation, collective dynamics.

\section{ACKNOWLEDGMENTS}

The authors express their sincere gratitude to all the staff of the Center for Collective Use of Scientific Equipment of Voronezh State University. URL: http://ckp.vsu.ru

\section{CONFLICT OF INTEREST}

The authors declare the absence of obvious and potential conflicts of interest related to the publication of this article.

\section{REFERENCES}

1. Tret'yakov Yu. D. Self-organisation processes in the chemistry of materials. Uspekhi khimii [Russian Chemical Reviews], 2003, v. 72(8), pp. 651-679. DOI: 10.1070/RC2003v072n08ABEH000836

2. Kushnir S. E., Kazin P. E., Trusov L. A., Tret'yakov Yu. D. Self-organization of micro- and nanoparticles in ferrofluids. Uspekhi khimii [Russian Chemical Reviews], 2012, v. 81(6), pp. 560-570. DOI: 10.1070/ RC2012v081n06ABEH004250

3. Lebedev-Stepanov P. V., Kadushnikov R. M., Molchanov S. P., Ivanov A. A., Mitrokhin V. P., Vlasov K. O., Rubin N. I., Yurasik G. A., Nazarov V. G., Alfimov M. V. Self-assembly of nanoparticles in the microvolume of colloidal solution: Physics, modeling, and experiment. Rossiiskie nanotekhnologii [Nanotechnologies in Russia], 2013, v. 8(3-4), pp. 137-162. DOI: $10.1134 / \mathrm{S} 1995078013020110$

4. Walker D. A., Kowalczyk B., Cruz M. O., Grzybowski B.A. Electrostatics at the nanoscale. Nanoscale, 2011, v. 3(4), pp. 1316-1344. DOI: 10.1039/C0NR00698J

5. Ouyang Q., Castets V., Boissonade J., et al. Sustained patterns in chlorite-iodide reactions in a one- dimensional reactor. J. Chem. Phys., 1991, v. 95(1), pp. 351-360. DOI: 10.1063/1.461490

6. Tarasevich Yu. Yu., Pravoslavnova D. M. Kachestvennyy analiz zakonomernostey vysykhaniya kapli mnogokomponentnogo rastvora na tverdoy podlozhke [Qualitative analysis of patterns of drying of a drop of a multicomponent solution on a solid substrate], Zhurnal tekhnicheskoi fiziki [Technical Physics], 2007, vol. 77, no. 2. pp. 17-21. URL: http://journals.ioffe. $\mathrm{ru} /$ articles/viewPDF/9047 (in Russ.)

7. Faigl' F., Anger V. Kapel'nyi analiz neorganicheskikh veshchestv [Drip Analysis of Inorganic Substances]. Moscow, Mir Publ., 1976, v. 1, 390 p., v. 2, 320 p. (in Russ.)

8. Yakhno T. A., Kazakov V. V., Sanina O. A., Sanin A. G., Yakhno V. G. Kapli biologicheskikh zhidkostey, vysykhayushchie na tverdoy podlozhke: dinamika morfologii, massy, temperatury i mekhanicheskikh svoystv [Drops of biological fluids drying on a solid substrate: dynamics of morphology, mass, temperature, and mechanical properties].Zhurnal tekhnicheskoi fiziki [Technical Physics], 2010, v. 80(7), pp. 17-23. URL: http://journals.ioffe.ru/articles/ viewPDF/10043 (in Russ.)

9. Alfimov M.V., Kadushnikov R. M., Shturkin N. A., Alievskii V. M., Lebedev-Stepanov P. V. Immitatsionnoe modelirovanie protsessov samoorganizatsii nanochastits [Simulation modeling of self-organization processes of nanoparticles], Rossiiskie nanotekhnologii [Nanotechnologies in Russia], 2006, v. 1(1-2), pp. 127133. (in Russ.)

10. Lebedev-Stepanov P. V., Gromov S. P., Molchanov S. P., Chernyshov N. A., Batalov I. S., Sazonov S. K., Lobova N. A., Shevchenko N. N., Men'shikova A. Yu., 
Alfimov M. V. Controlling the self-assemblage of modified colloid particle ensembles in solution microdropletsRossiiskie nanotekhnologii [Nanotechnologies in Russia], 2011, v. 6(9-10), 569-578, pp. 72-78. DOI: $10.1134 /$ S1995078011050119

11. Andreeva L.V., Novoselova A. S., Lebedev-Stepanov P. V., Ivanov D. A., Koshkin A. V., Petrov A. N., Alfimov M.V.Zakonomernosti kristallizatsii rastvorennykh veshchestv iz mikrokapli [Patterns of crystallization of dissolved substances from microdrops]. Zhurnal tekhnicheskoi fiziki [Technical Physics], 2007, v. 77(2), pp. 22-30. URL: http://journals.ioffe.ru/articles/viewPDF/9048 (in Russ.)

12. Barash L. Yu. Marangoni convection in an evaporating droplet: Analytical and numerical descriptions. International Journal of Heat and Mass Transfer, 2016, v. 102, pp. 445-454. DOI: 10.1016/j.ijh eatmasstransfer.2016.06.042 al

13. Bityutskaya L. A., Zhukalin D. A., Tuchin A. V., Frolov A. A., Buslov V. A. Thermal dissipative structures in the case of carbon nanotubes aggregation in drying drops. Kondensirovannye sredy i mezhfaznye granitsy [Condensed Matter and Interphase], 2014, v. 16(4), pp. 425-430. URL: https://journals.vsu.ru/kcmf/ article/view/856/937 (in Russ.)

14. Asakura S., Oosawa F. Interaction between particles suspended in solutions of macromolecules. Polymer Science Part A: General Papers, 1958, v. 33(126), pp. 183-192. DOI: 10.1002/pol.1958.1203312618

15. Minton A. P. How can biochemical reactions within cells differ from those in test tubes? Journal of Cell Science, 2015, v. 119(14), pp. 2863-2869. DOI: 10.1242/jcs.03063

16. Chebotareva N. A., Kurganov B. I., Livanova N. B. Biochemical effects of molecular crowding.
Biohimija [Biochemistry], 2004, v. 69(11), pp. 12391251. DOI: 10.1007/s10541-005-0070-y

17. Bishop K. J., Wilmer C. E., Soh S., Grzybows$\mathrm{ki}$ B. A. Nanoscale forces and their uses in self-assembly. Small, 2009, v. 5(14), p. 1600-1630. DOI: 10.1002/ smll.200900358

18. Minton A. P. The influence of macromolecular crowding and macromolecular confinement on biochemical reactions in physiological media. Journal of Biological Chemistry, v. 276(14), pp. 10577-10580. DOI: 10.1074/jbc.r100005200

19. Huber F., Strehle D., Schnauss J., Kas J. Formation of regularly spaced networks as a general feature of actin bundle condensation by entropic forces. New J. Physics, 2015, v. 17(4), p. 043029. DOI: 10.1088/13672630/17/4/043029

20. Jiang H., Wada H., Yoshinaga N., Sano M. Manipulation of colloids by a nonequilibrium depletion force in a temperature gradient. Physical Review Letters, 2009, v. 102(20), p. 208301. DOI: 10.1103/ physrevlett.102.208301

21. Deng H., Li G., Liu H. Assembling of three-dimensional crystals by optical depletion force induced by a single focused laser beam. Optics Express, 2012, v. 20(9), p. 9616. DOI: 10.1364/oe.20.009616

22. Wulfert R., Seiferta U., Speck T. Nonequilibrium depletion interactions in active microrheology. Soft Matter, 2017, v. 13(48), p. 9093-9102. DOI: 10.1039/ c7sm01737e

23. Dolgih I. I., Bitutskaya L. A. Entropy driven aggregation of CNT in a drying drop on hydrophilic and hydrophobic substrate. Kondensirovannye sredy $i$ mezhfaznye granitsy [Condensed Matter and Interphase], 2018, v. 20(4), p. 664-668. DOI: 10.17308/ kcmf.2018.20/635
Долгих Игорь Игоревич - аспирант кафедры физики полупроводников и микроэлектроники, Воронежский государственный университет, Воронеж, Российская Федерация; e-mail:dolgih_igor@ yahoo.com. ORCID iD 0000-0002-9508-7123.

Жукалин Дмитрий Алексеевич - к. ф.- м. н, доцент кафедры физики полупроводников и микроэлектроники, Воронежский государственный университет, Воронеж, Российская Федерация; e-mail:d.zhukalin@mail. ru. ORCID iD 0000-0002-0754-4989.

Битюцкая Лариса Александровна - к. х. н, доцент кафедры физики полупроводников и микроэлектроники, Воронежский государственный университет, Воронеж, Российская Федерация; e-mail: lab55fm@yandex.ru. ORCID iD 0000-00020767-2614.
Dolgih Igor Igorevich - postgraduate student, Department of Physics of Semiconductors and Microelectronics, Voronezh State University, Voronezh, Russian Federation; e-mail: dolgih_igor@yahoo. com. ORCID iD 0000-0002-9508-7123.

Zhukalin Dmitry Alekseevich - Cand. Sci. (Phys.Math.), Associate Professor of the Department of Physics of Semiconductors and Microelectronics, Voronezh State University; Voronezh, Russian Federation; e-mail: d.zhukalin@mail.ru. ORCID iD 0000-0002-0754-4989.

Bityutskaya Larisa Alexandrovna - Cand. Sci. (Chem.), Associate Professor of the Department of Physics of Semiconductors and Microelectronics, Voronezh State University; Voronezh, Russian Federation; e-mail: lab55fm@yandex.ru. ORCID iD 0000-0002-0767-2614. 